\title{
The Laptev Sea system since the last glacial
}

\author{
H. Kassens \\ Leibniz Institute for Marine Sciences, Wischhofstr. 1-3, 24148 Kiel, Germany \\ J. Thiede \\ Alfred Wegener Institute for Polar and Marine Research, Bremerhaven, Germany
}

H.A. Bauch

Mainz Academy of Sciences, Humanities and Literature, Germany

J.A. Hoelemann

Alfred Wegener Institute for Polar and Marine Research, Bremerhaven, Germany

I. Dmitrenko

International Arctic Research Center (IARC), University of Alaska-Fairbanks, Fairbanks, Alaska, USA

\section{S. Pivovarov \\ S. Priamikov \\ L. Timokhov}

Arctic and Antarctic Research Institute, St. Petersburg, Russia

\author{
C. Wegner \\ Leibniz Institute for Marine Sciences, Wischhofstr. 1-3, 24148 Kiel, Germany
}

\begin{abstract}
There is growing concern about the rapidity and extent of climate change in recent decades in the Arctic. The changes already evident in the Arctic, such as the cyclonic shift in the distribution of Atlantic and Pacific water masses, atmospheric pressure and winds, as well as the thinning and retreat of the sea ice, will be felt first and most dramatically around the circum-Arctic shelves, which comprise nearly $50 \%$ of the area of the Arctic Ocean. In this context, the Laptev Sea and its Siberian hinterland are of particular interest because of their distance both from the Atlantic and Pacific Oceans. River discharge into the Laptev Sea constitutes a key source for the Arctic freshwater input, and it generates a shallow brackish layer on top of the halocline. The shallow Laptev Sea shelf is a major area of sea-ice production that links the Siberian shelves of the Arctic Ocean with the Nordic seas. During the Last Glacial Maximum, most of these shelves were above sea level and developed thick permafrost sequences; today they are submarine, after having experienced the postglacial late Pleistocene and Holocene transgression. The history of the submarine permafrost and its modern state of decay are largely unknown.
\end{abstract}

Keywords: Arctic shelf sea, River Lena, flaw polynya, permafrost.

Kassens, H., Thiede, J., Bauch, H.A., Hoelemann, J.A., Dmitrenko, I., Pivovarov, S., Priamikov, S., Timokhov, L., and Wegner, C., 2007, The Laptev Sea system since the last glacial, in Harff, J., Hay, W.W., and Tetzlaff, D.M., eds., Coastline Changes: Interrelation of Climate and Geological Processes: Geological Society of America Special Paper 426, p. 89-96, doi: 10.1130/2007.2426(06). For permission to copy, contact editing@geosociety.org. @2007 The Geological Society of America. All rights reserved. 


\section{INTRODUCTION}

During the past decade, a large-scale change in the Arctic atmospheric circulation took place as part of a pole-centered pattern termed the Arctic Oscillation (e.g., Thompson and Wallace, 1998; Monahan et al., 2000; Mysak, 2001; AClA, 2004). There is a complex of related atmospheric, oceanic, and terrestrial changes, including an increased discharge of fresh water from the six largest Eurasian rivers to the Arctic Ocean (Peterson et al., 2002), reduced sea-ice extent and volume (e.g., Serreze et al., 2000; Johannessen et al., 2004), and increased air temperature over most of the Arctic (Proshutinsky and Johnson, 1997; Jones and Moberg, 2003). Freshening of the Arctic Ocean is expected to reduce North Atlantic Deep Water formation and Atlantic thermohaline circulation (e.g., Broecker, 1997; Rahmstorf and Ganopolski, 1999; Delworth and Dickson, 2000), but the precise nature of any future changes is unknown, and because of their impact on the livelihood of high Northern Hemisphere populations, they are subject of intense scientific and political debate.

The positive temperature trend in the Russian Arctic favors decay and thawing of terrestrial permafrost (Pavlov, 1994; Goldman, 2002; Nelson, 2003; ACIA, 2004). The submarine permafrost regime is largely determined by heat and mass transport processes that control the response rate to the new warm and salty boundary conditions (e.g., Osterkamp et al., 1989; Gosink and Baker, 1990). A considerable amount of organic carbon is stored in the upper layer of permafrost, and gas hydrates are expected within and beneath the submarine permafrost (Romanovsky et al., 2004; Romanovsky et al., 2005). Large increases of $\mathrm{CO}_{2}$ and $\mathrm{CH}_{4}$ emissions are expected to be associated with degradation of the permafrost (Nelson, 2003). Thawing of the permafrost could release large quantities of greenhouse gases into the atmosphere, thus further increasing global warming. Taking into account these concerns, extensive studies of the water column and seafloor of the Laptev Sea shelf and of the environment of its hinterland have been carried out during all seasons of the year in the scope of the research program "Laptev Sea System" (Kassens et al., 1999; Larsen et al., 1999; Thiede, 2004; Bauch and Kassens, 2005) (Fig. 1). The primary scientific goal was to decipher the mechanisms that controlled past climate variations as well as those controlling ongoing environmental changes.

\section{MODERN AND PAST ENVIRONMENT OF THE LAPTEV SEA SHELF}

Environmental forcing factors, i.e., atmospheric circulation, sea-ice cover, and river runoff, mainly affect the shallow-water environment of the Laptev Sea (Eicken et al., 2005). In particular, the predominance of cyclonic or anticyclonic atmospheric circulation over the Arctic influences the current system and the distribution of river runoff on the shelf (Proshutinsky et al., 2001). The wind-forced Laptev Sea flaw polynya, open water between pack and fast ice, is one of the key elements of the environmental system of the Laptev Sea (Bareiss and Görgen, 2005) (Fig. 2).
Continuous southerly winds that blow during the whole winter season are able to maintain open-water areas, up to one hundred kilometers wide, between the fast and drift ice, despite the low temperatures of air and sea-surface waters. Year-round measurements with acoustic doppler current profilers and oceanographic data have shown that the water column in the polynya region of the SE Laptev Sea is stratified during all seasons (Dmitrenko et al., 2002, 2005). Low air and seawater temperatures result in sea-ice formation and local increases of salinity in the water column. For instance, in the eastern Laptev Sea flaw polynya, the mean salinity increase of the surface layer can reach up to 4 units, corresponding to an ice production of 3 to $4 \mathrm{~m}$ (Dmitrenko et al., 2001a). Therefore, the flaw polynya is an important ice source for the Transpolar Drift system (Alexandrov et al., 2000). Regardless of the strong ice formation, the low initial salinity of the surface layer and the strong density stratification in the polynya prevent a convective mixing down to the seafloor. Thus, this stratified system limits the transport of energy as well as of particulate and dissolved matter (Pivovarov et al., 2004) (Fig. 3).

Like the wind-forced dynamics of the ice regime, sediment transport is also strongly affected by different regimes of atmospheric circulation and ice cover. New data show that this effect starts as soon as the Laptev Sea flaw polynya opens up during winter (Dmitrenko et al., 2001b, 2005). Long-term measurements with bottom-moored instruments provide strong evidence that modern shelf sediment transport is mainly wind-forced and connected to the N-S-running submarine valleys on the shelf of the eastern Laptev Sea (Wegner et al., 2003, 2005). In these valleys, suspended sediments are transported in a distinct bottom nepheloid layer, a layer of increased suspended matter concentration up to $12 \mathrm{~m}$ thick, which is strongly influenced by the prevailing atmospheric circulation and the ice cover (Burenkov et al., 1997; Dmitrenko et al., 2001b; Wegner et al., 2003). Calculations of the net horizontal sediment flux during the ice-free period have revealed that the main transport within the bottom nepheloid layer in the submarine valleys is directed toward the inner shelf (Wegner et al., 2003). With respect to the sediment export from the eastern Laptev Sea shelf into the deep Arctic Ocean, Wegner et al. (2005) inferred that during the ice-free period, most of the material derived from riverine input is trapped within a quasi-estuarine circulation system on the inner and mid-shelf regions. This pattern of sediment transport might also explain the low sediment accumulation rates on the outer shelf and the slope of the Laptev Sea since the end of the Holocene transgression (Bauch et al., 2001; Stein et al., 2001). If the net sediment transport in the bottom nepheloid layer is directed toward the central and inner shelf, and if we fur. ther take into account that large areas of the Laptev Sea are covered by relict sediments and lag deposits (Viscosi-Shirley et al., 2003) with no present-day sediment deposition, we can draw the conclusion that the sediment input into the Laptev Sea is not balanced by sediment deposition on the shelf and long-range export through the water column to the Arctic basins. This discrepancy in sediment budgets may be explained by an eastward sediment transport to the East Siberian Sea that follows the Siberian Coastal 


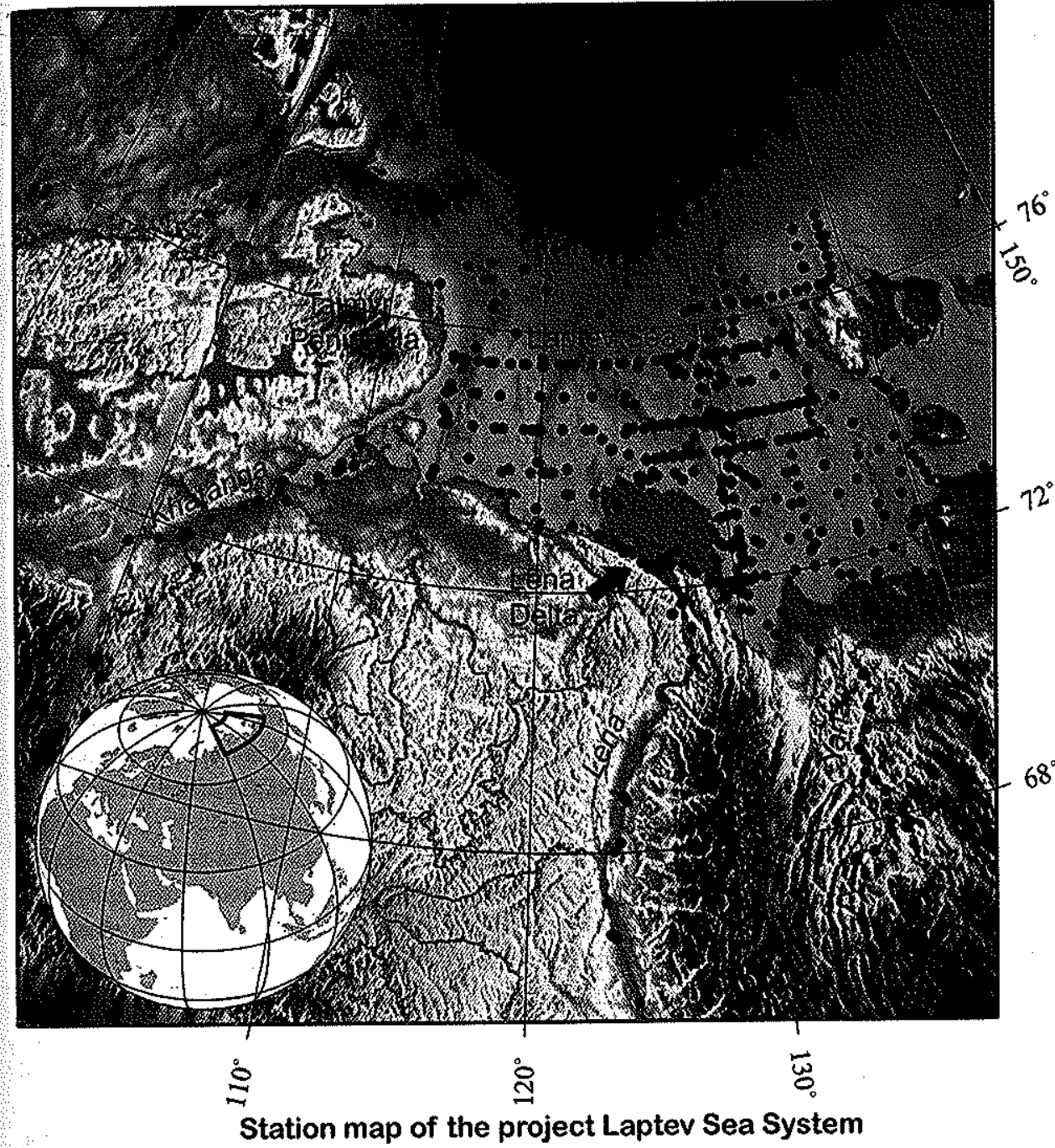

Figure 1. Station map of the Laptev Sea System project in the Siberian Arctic.

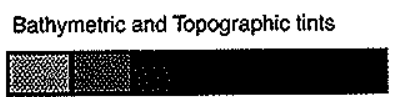

detasource: IBCAO (International Bathymetric Chart of the Arctic Ocean http:/www.ngda.noaa gov/mgg/bathymetry/arctic/anctia.titul projection: Lambert azimuthal equal-area projection (122 E/75 N) $\begin{array}{lllllll}0 & -25 & -50 & -200 & -1000 & -3000 & -5000 \mathrm{~m}\end{array}$ mas by: T. Muethor-LupD (GEOMAR)

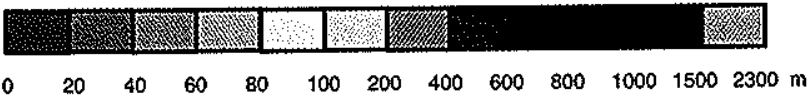

Current (Viscosi-Shirley et al., 2003) and a long-range transport of sediments by sea ice (Wegner et al., 2005).

Evidence has accumulated over the past two decades that demonstrates that the entrainment of sediments into sea ice is a common phenomenon on the shallow Siberian shelves (Reimnitz et al., 1993; Eicken et al., 1997). It has been shown that even under calm weather conditions, the freezeup during October seems to be an important time period for sediment transport by sea ice from the shallow shelf areas of the Laptev Sea toward the Arctic basin (Lindemann et al., 1999). By combining field measurements, remote sensing, and numerical modeling, Eicken et al. (2000) were able to identify the shallow shelf near the New Sibe- rian Islands as a key site for ice entrainment and a basinwide dispersal of sediments by sea ice. They documented a total ice-bound sediment export of 18.5 million tons for one entrainment event in 1994-1995. Another possible mechanism for the formation of sediment-laden sea ice is the resuspension of fine-grained bottom sediments in the polynya area and the subsequent entrainment of these sediments into newly formed ice (Pfirman et al., 1990; Nürnberg et al., 1994; Rigor and Colony, 1997; Eidsvik, 2000). Recent studies have shown that the Laptev Sea is one of the major source areas for sea ice in the Transpolar Drift System (Rigor and Colony, 1997; Alexandrov et al., 2000) and a center of sediment entrainment by ice (Pfirman et al., 1990; Darby, 2003). However, 


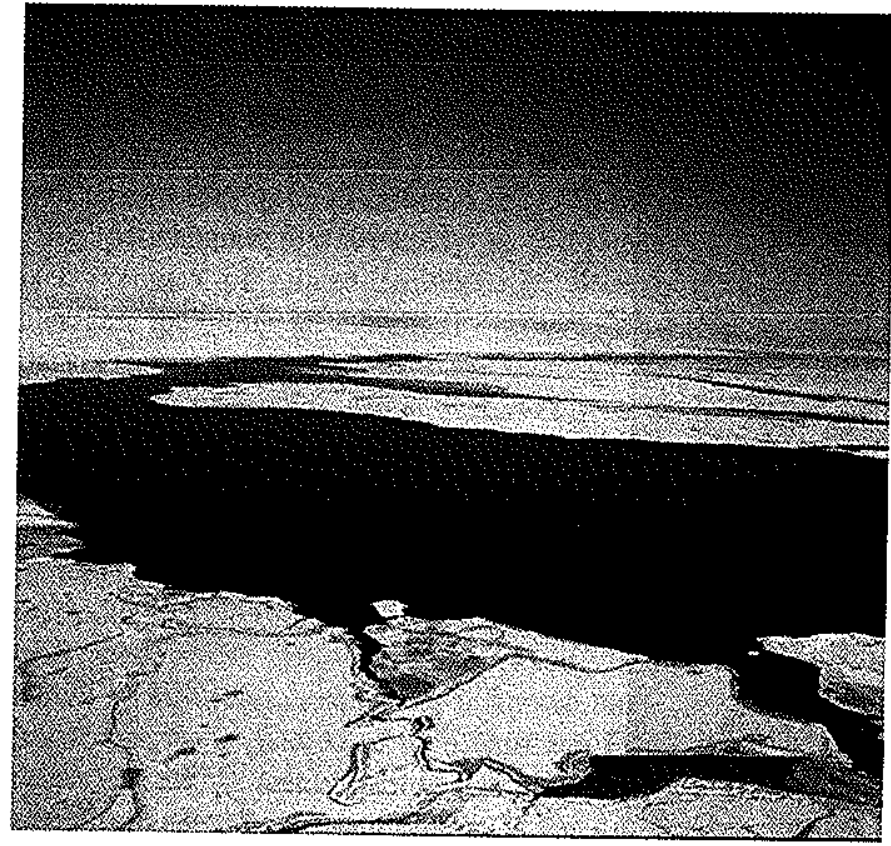

Figure 2. The Laptev Sea flaw polynya (roughly $1 \mathrm{~km}$ wide) north of the Lena Delta in Aptil 1999.

the general idea that suspension freezing during sea-ice formation in the winter polynya is the dominant sediment entrainment process in the Laptev Sea is in conflict with the field observations of Dmitrenko et al. (2001a), who have shown that even during winter, the strong density stratification of the water column, especially in the eastern Laptev Sea, prevents convection from penetrating down to the seafloor. Thus, resuspension of fine-grained bottom sediments accompanied by suspension freezing beneath the polynya is unlikely to occur in the eastern Laptev Sea. This supports the hypothesis that the fall freezeup (October) might also be an important and as yet underestimated period for the formation and export of sediment-laden sea ice. The incorporation of sediments into newly formed ice is not only important for the transport of sediments, Arctic sea ice also plays a crucial role for the large-scale transport and cycling of trace elements (Rigor and Colony, 1997) and radionuclides (Meese et al., 1997). Within the framework of an interdisciplinary field study of freezeup processes in the Laptev Sea, Hölemann et al. (1999) observed that the concentrations of dissolved $\mathrm{Mn}, \mathrm{Fe}, \mathrm{Zn}, \mathrm{Cd}$, and $\mathrm{Pb}$ in newly formed sediment-laden ice were up to 40 times higher than the dissolved concentrations that were measured in seawater and fresh water in the region of ice formation. The elevated concentrations of dissolved trace metals in the newly formed ice were probably caused by a remobilization of trace elements from the ice-rafted sediment particles. This mechanism can play an important role for the dispersal of trace elements through the Arctic environment. As an example, Winter et al. (1997) have shown that the primary source of rare earth elements and $\mathrm{Pb}$ for the dissolved reservoir in Arctic seawater is not river water, but ice-rafted debris, which through dissolution or exchange processes is an important source of trace elements for seawater in ice-covered oceans. This is supported by Measures (1999), who observed that Arctic Ocean surface waters with the highest reactive $\mathrm{Al}$ and reactive $\mathrm{Fe}$ values appear to coincide in many cases with the presence of high concentrations of ice-rafted sediments. The author presumed that the seasonal melting of ice containing rafted sediments added particulate and dissolved trace metals to Arctic surface waters.

Another key element of the modern environment of the Laptev Sea and the transport processes between this marginal sea and the Arctic basin is the spring freshet of the Lena River (Pivovarov et al., 1999; Hölemann et al., 2005). During the high discharge period in May and June, $\sim 30 \%$ of the annual runoff and $60 \%$ of suspended sediments are discharged onto the stillice-covered shelf. In the course of the freshet, riverine dissolved and particulate substances are transported in a freshwater layer beneath the fast ice of the Laptev Sea (Pivovarov et al., 1999). These river-to-sea transport processes show strong interannual variations because the dynamics of the spring flood and the extension of the fast ice in spring are controlled by short-term atmospheric processes.
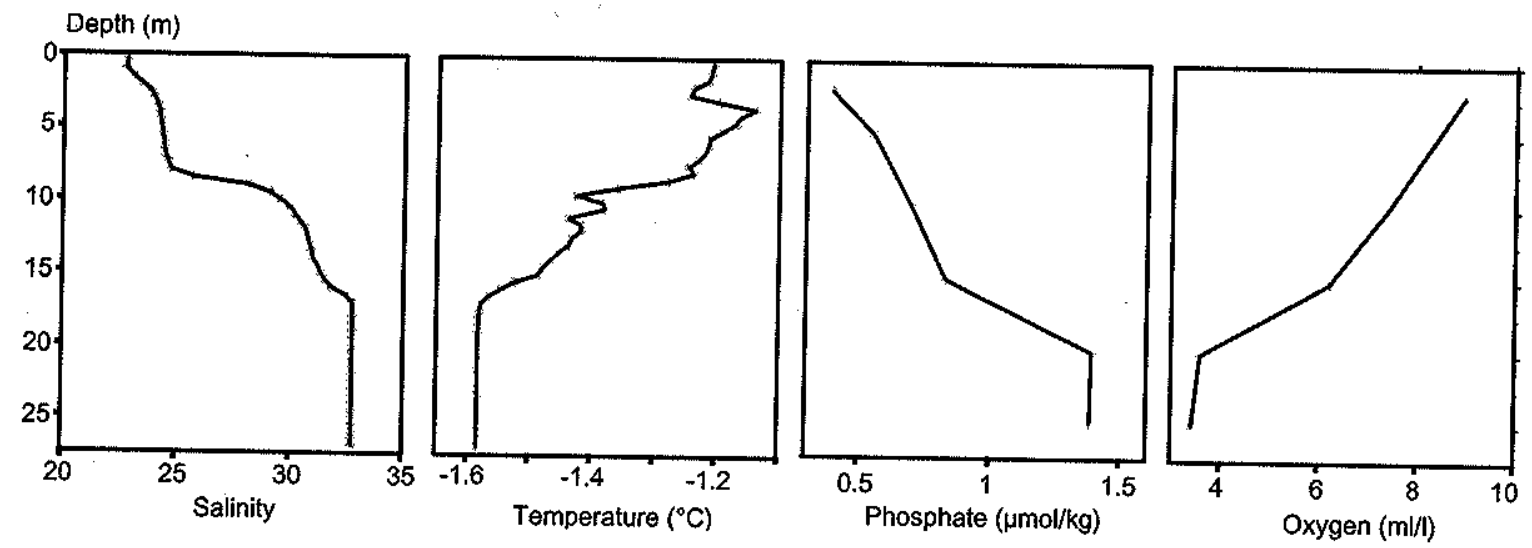

Figure 3. The two-layer system of the water column in the polynya north of the Lena Delta in spring 1999. The strong stratification limits the exchange of oxygen and phosphate between the bottom and surface waters. Remineralization of organic matter near/at the seafioor results in a depletion of oxygen and an enrichment in phosphate. 
River runoff has a pronounced influence on the distribution, activity, and community structure of the phytoplankton and zooplankton in the whole shelf region (Abramova, 2000; Tuschling, 2000; Bauch and Polyakova, 2003; Pivovarov et al., 2004). Triggered by the Lena River discharge, this influence varies during the seasons and shows the highest impact on the ecosystem in spring and early summer, when outflow rates are high. The strong seasonal and interannual variability not only affects the phytoplankton distribution (Abramova and Tuschling, 2005) but also leaves a mark on the spatial distribution of benthic communities (Stepanova et al., 2003) as well as their geochemical signature (Müller-Lupp et al., 2003; Müller-Lupp and Bauch, 2005).

Radiocarbon-dated gravity cores up to $9 \mathrm{~m}$ in length have been recovered from the Laptev Sea shelf. Their chronologies provide a detailed reconstruction of the Laptev Sea inundation history since early Holocene times (Bauch et al., 2001). Paleosalinity reconstructions based on diatoms and benthic foraminiferal $\delta^{18} \mathrm{O}$ from these cores indicate that Holocene river input into the eastern Laptev Sea has been governed by dominantly cyclical behavior. While the diatom record primarily reflects the southward retreat of the coastline during the postglacial transgression between 9000 and $7000 \mathrm{yr}$ ago, as well as variable sea-ice conditions during the later Holocene, the foraminiferal data indicate changes in bottomwater salinity with a recurrence interval of $1000 \mathrm{yr}$ over the past $8500 \mathrm{yr}$ (Bauch and Polyakova, 2003). Although global transgression in the Laptev Sea came to an end $\sim 5000$ yr ago, modern environment conditions were established only during the later phase of the Holocene transgression, which reached the southern region of the Laptev Sea between 7000 and 5000 yr ago.

In order to study Arctic climate change on time scales beyond the Holocene, a drilling campaign was conducted on the outer Laptev Sea shelf in 2000 (Kassens et al., 2001). Radiocarbon ages and micropaleontological data show a Holocene sediment package that is $\sim 10 \mathrm{~m}$ thick. The cores recovered during the drilling campaign from below this depth level reveal various types of ice-bearing sediments (Fig. 4) that contain a rich terrestrial plant flora as well as remains of beetle faunas, implying a late glacial age in accordance with radiocarbon data (Kassens et al., 2001). However, there is evidence that the stability of the permafrost is presently threatened due to global warming. Such a change would be of major climatic significance, considering the potential release of gas hydrates now trapped in the frozen ground.

The Laptev Sea shelf represents the southern rim of the Eurasian Arctic Ocean basin in northern Russian (Fig. 5), where there is a currently active spreading axis, the Gakkel Ridge, which is the divergent boundary between the North American and the Eurasian plates in the Arctic. Gakkel Ridge, the world's slowest spreading mid-ocean ridge (Jokat et al., 2003; Michael et al., 2003), approaches the Laptev Sea shelf at a right angle and terminates against a steep continental slope with a complex tectonic structure. Multichannel seismic-reflection studies, carried out over the Laptev Sea shelf during the past two decades, have revealed a vast rift system with a very slow spreading rate of $0.3 \mathrm{~cm} / \mathrm{yr}$ (Ivanova et al., 1990; Drachev et al., 1999; Drachev, 2000; Roeser et al.,

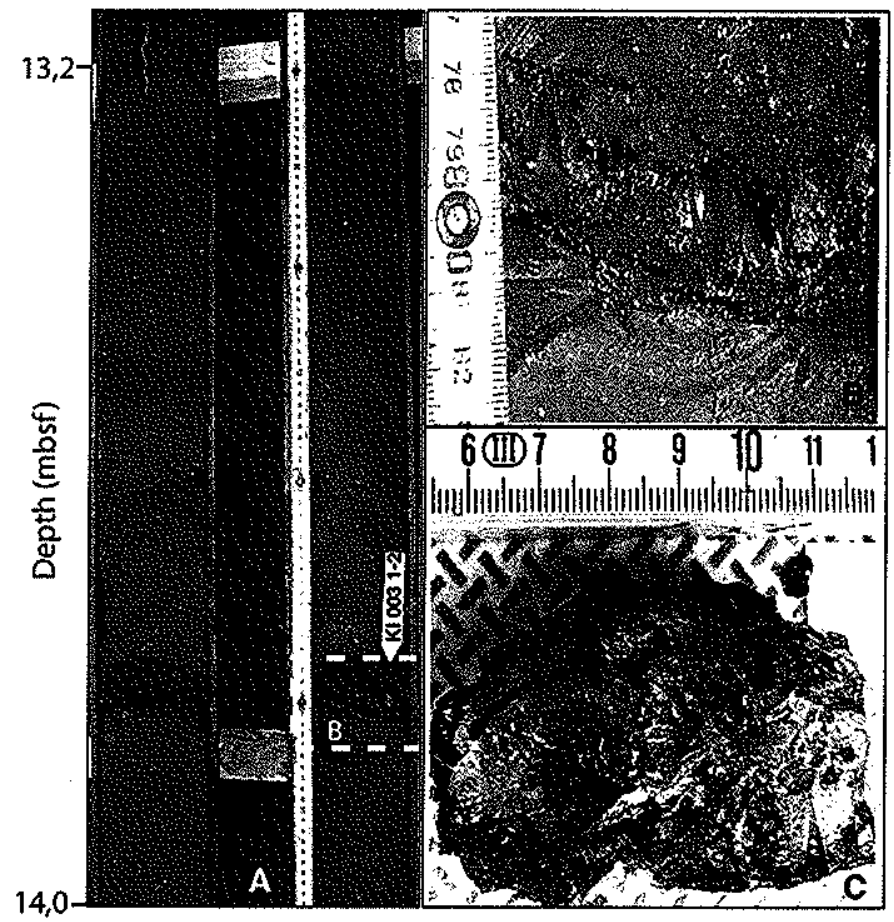

Figure 4. (A) Ice-bearing submarine permafrost in the eastern Laptev Sea at $33 \mathrm{~m}$ water depth (KIO03-1-2; cored interval 13.13-14.00 m below seafloor [mbsf]). (B) Lens of segregated ice in fine-grained near-surface sediments, enlargement of Figure 4A. (C) Surface view of the ice lens.

1995; Hinz et al., 1998; Franke et al., 2000). Its origin is related to the opening of the Eurasian Basin and the evolution of the Gakkel spreading center. This process started $~ 58$ million yr ago and has remained active through the whole Cenozoic (Karasik, 1974; Vogt et al., 1979; Savostin et al., 1984). The Laptev Sea shelf is one of a few places worldwide where a currently active mid-ocean-ridge system approaches a continental margin. The high tectonic activity of this region is resulting in fault formation and earthquakes along the major structural elements. Considering that ice-bonded and ice-bearing sediments with thicknesses of several hundred meters have been verified by seismic records, the Laptev Sea shelf is a very sensitive area in terms of stability and global climate changes. Pockmark features, which have diameters that vary between 100 and $600 \mathrm{~m}$ and are presumably caused by expulsion of fluids and gases as discussed by Hinz et al. (1998), as well as open taliks as proposed by Romanovsky et al. (2004), are suggested to be the first indicators of ongoing changes.

\section{CONCLUSIONS}

The changing environment of the Arctic may also alter the aquatic biogeochemical cycles and thus the fluxes of materials like climate-relevant trace gases through the marine Arctic environment. Especially over the broad Siberian continental shelves, the balance between terrestrial and benthic inputs and marine production of organic carbon is strongly dependent on 

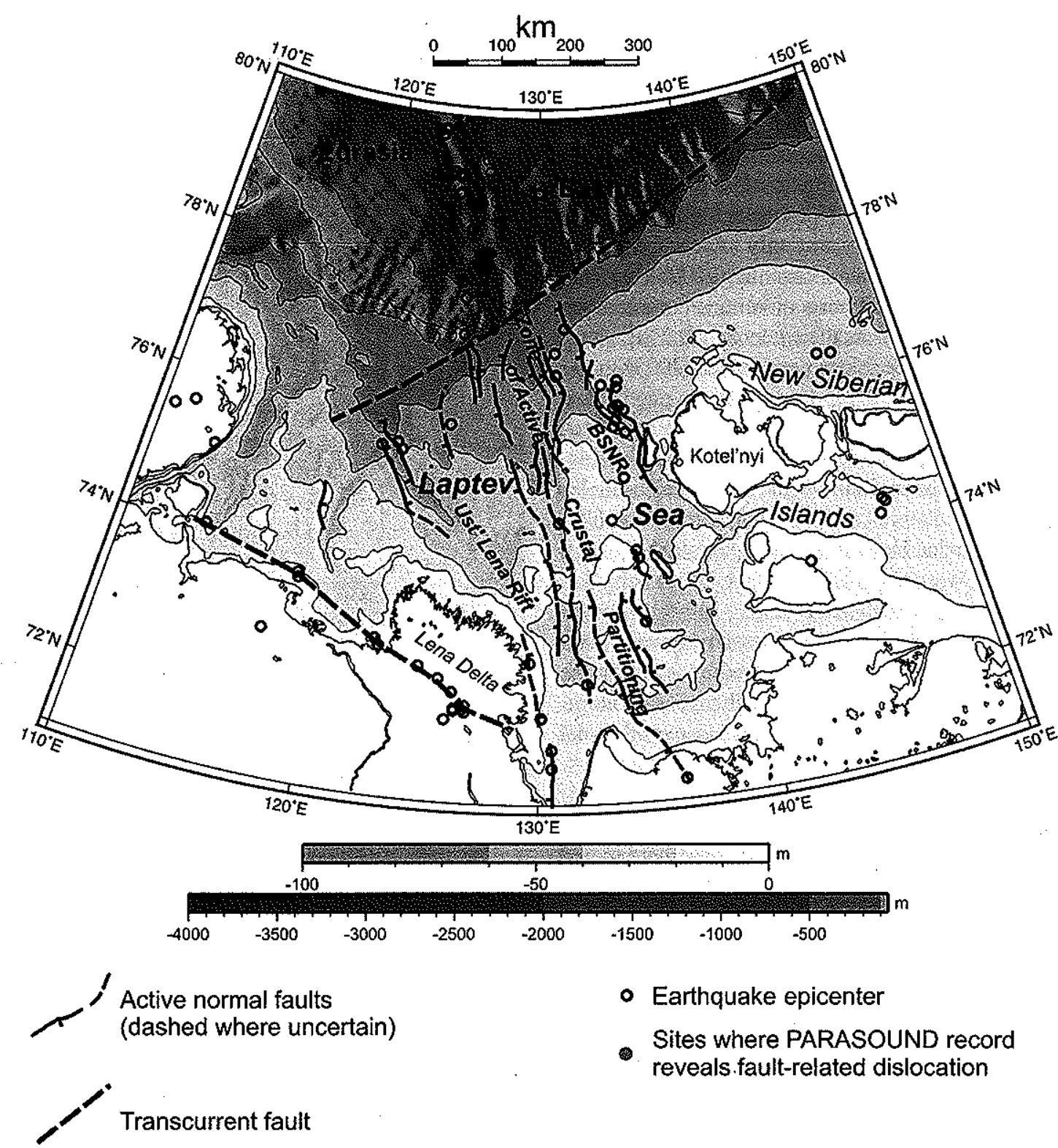

- Earthquake epicenter

- Sites where PARASOUND record reveals.fault-related dislocation

Figure 5. Main structural elements of the Laptev Sea shelf (after Drachev, 2000). BSNR-Bel'kov-Svyatoi Nos Rift.

seasonal changes in light levels, ice cover, and freshwater input. As a consequence, marine biogeochemical cycles may respond strongly to the ongoing climatic changes and amplified variations of abiotic factors.

Only a research strategy that combines satellite-based information with data from ocean observatories and the ability to conduct year-round measurements of key hydrographic, biological, and chemical parameters under extremely harsh environmental conditions can provide new insights into the recent changes of the Arctic environment and how they may alter the transfer of materials and energy through the Arctic geo-ecosystem. Key areas for these new and essential studies are the broad Eurasian Arctic shelf seas, like the Laptev Sea, which have a blanket of highly variable and dynamic sea-ice cover and seafloors underlain by submarine permafrost, with its unique specialized microbial communities that control the turnover and benthic fluxes of carbon and other climate-relevant elements.

\section{ACKNOWLEDGMENTS}

We wish to thank the German and Russian Ministries of Science and Technology for their financial and logistic support (LAPEX, BMBF 52503G0517, BMBF 03PL009, BMBF 03G0569, BMBF 03PLO26, BMBF03PLO37, BMBF 03G0589). Comments by two anonymous reviewers were very helpful in improving the manuscript. 


\section{REFERENCES CITED}

Abramova, E.N., 2000, Pelagic invertebrate fauna of the Laptev Sea shelf [Ph.D. diss.]: St. Petersburg, Institute of Zoology, Russian Academy of Sciences, 190 p. (in Russian).

Abramova, E., and Tuschling, K., 2005, A 12-year study of the seasonal and interannual dynamics of mesozooplankton in the Laptev Sea: Significance of salinity regime and life cycle patterns: Global and Planetary Change, Special Issue, v. 48 , no. 1-3, p. 141-164, doi: 10.1016 / j.gloplacha.2004.12.010, doi: 10.1016/j.gloplacha.2004.12.010.

ACIA (Arctic Climate Impact Assessment), 2004, Impacts of a Warming Arctic: Arctic Climate Impact Assessment: Cambridge, Cambridge University Press, $140 \mathrm{p}$.

Alexandrov, V.Y., Martin, T., Kolatschek, J., Eicken, H., and Kreyscher, M., 2000, Sea ice circulation in the Laptev Sea and ice export to the Arctic Ocean: Results from satellite remote sensing and numerical modelling: Journal of Geophysical Research, v. 105, no. C5, p. 17143-17159, doi: 10.1029/2000JC 900029 .

Bareiss, J., and Görgen, K., 2005, Spatial and temporal variability of sea ice in the Laptev Sea: Analyses and review of satellite passive-microwave data and model results, 1979 to 2002: Global and Planetary Change, v. 48 , no. $1-3$, p. $28-54$, doi: $10.1016 /$ j.gloplacha.2004.12.004, doi: $10.1016 /$ j.gloplacha.2004.12.004.

Bauch, H.A., and Kassens, H., 2005, Arctic Siberian shelves: Global and Planetary Change, Special Issue, v. 48 , no. 1-3, p. 1-8, doi: $10.1016 /$ j.gloplacha.2004.12.003.

Bauch, H.A., and Polyakova, Y.I., 2003, Diatom-inferred salinity records from the arctic Siberian margin: Implications for fluvial runoff patterns during the Holocene: Palaeoceanography, v. 18 , no. 2, p. 1027 , doi: $10.1029 / 2002$ PA000847.

Bauch, H.A., Müller-Lupp, T., Spielhagen, R.F., Taldenkova, E., Kassens, H., Grootes, P.M., Thiede, J., Heinemeier, J., and Petryashov, V.V., 2001, Chronology of the Holocene transgression at the northern Siberian margin: Global and Planetary Change, v. 31 , no. $1-4$, p. 125-139, doi: 10.1016/S0921-8181(01)00116-3.

Broecker, W.S., 1997, Thermohaline circulation, the Achilles heel of our climate system: Will man-made $\mathrm{CO}_{2}$ upset the current balance?: Science, v. 278 , p. $1582-1588$, doi: $10.1126 /$ science. 278.5343 .1582 .

Burenkov, V.I., Kuptzov, V.M., Sivkov, V.V., and Shevchenko, V.P., 1997, Spatial distribution and size composition of suspended matter in the Laptev Sea in August-September 1991: Oceanology (Moscow), v. 37, no. 6, p. 831-837.

Darby, D.A. 2003, Sources of sediment found in sea ice from the western Arctic Ocean, new insights into processes of entrainment and drift patterns: Journal of Geophysical Research, v. 108, no. C8, p. 3257, doi: $10.1029 / 2002 \mathrm{JC} 001350$.

Delworth, T.L., and Dickson, K.W., 2000, Implications of the recent trend in the Arctic/North Atlantic Circulation for the North Atlantic thermohaline circulation: Journal of Climate, v. 13, p. 3721-3727, doi: $10.1175 / 1520$ $0442(2000) 013<3721$ :IOTRTI $>2.0 . \mathrm{CO} ; 2$.

Dmitrenko, 1., Hölemann, J.A., Tyshko, K., Churun, V., Kirillov, S., and Kassens, H., 2001a, The Laptev Sea flaw polynya: Effect on the mesoscale hydrography: Annals of Glaciology, v. 33, p. 373-376.

Dmitrenko, I., Hölemann, J.A., Kirillov, S.A., Berezovskaya, S.L., Eicken, H., and Kassens, H., 200lb, Wind forced currents as a linkage between the Laptev Sea (Siberia) and the Arctic Ocean: Doklady Earth Science, MAIK Nauka, v. 377 , no. 1, p. 1-8.

Dmitrenko, I.A., Hölemann, J., Kirillov, S.A., Berezovskaya, S.L., Eicken, H., Ivanova, D., and Kassens, H., 2002, Transformation of baroclinic tidal internal waves under the influence of ice cover on the Laptev Sea shelf: Doklady Earth Sciences, v. 385, no. 5, p. 609-614.

Dmitrenko, I.A., Tyshko, K.N., Kirillov, S.A., Eicken, H., Hölemann, J.A., and Kassens, H., 2005, Impact of flaw polynyas on the hydrography of the Laptev Sea: Global and Planetary Change, Special Issue, v. 48, no. 1-3, p. 9-27, doi: 10.1016/j.gloplacha.2004.12.016.

Drachev, S.S., 2000, Laptev Sea rifted continental margin: Modern knowledge and unsolved questions: Polarforschung, v. 68, p. 41-50.

Drachev, S.S., Johnson, G.L., Laxon, S.W., Mcadoo, D.C., and Kassens, H., 1999, Main structural elements of eastern Russian Arctic continental margin derived from satellite gravity and multichannel seismic reflection data, in Kassens, H., Bauch, H.A., Dmitrenko, I.A., Eicken, H., Hubberten, H.-W., Melles, M., Thiede, J., and Timokhov, L.A., eds., Land-Ocean
Systems in the Siberian Arctic: Dynamics and History: Berlin, Springer, p. 667-682.

Eicken, H., Reimnitz, E., Alexandrov, V., Martin, T., Kassens, H., and Viehoff, T., 1997, Sea ice processes in the Laptev Sea and their importance for sediment export: Continental Shelf Research, v. 17, p. 205-233, doi: 10.1016/S0278-4343(96)00024-6.

Eicken, H., Kolatschek, J., Freitag, J., Lindemann, F., Kassens, H., and Dmitrenko, I., 2000, A key source area and constraints on entrainment for basin-scale sediment transport by Arctic sea ice: Geophysical Research Letters, v. 27, no. 13, p. 1919-1922, doi: 10.1029/1999GL011132.

Eicken, H., Dmitrenko, I., Tyshko, K., Darovskikh, A., Dierking, W., Blahak, U., Groves, J., and Kassens, H., 2005, Zonation of the Laptev Sea landfast ice cover and its importance in a frozen estuary: Global and Planetary Change, Special Issue, v. 48 , no. 1-3, p. 55-83, doi: 10.10161 j.gloplacha.2004.12.005.

Eidsvik, K.J., 2000, Coagulation of suspended sediments and ice crystals below leads: Cold Regions Science and Technology, v. 31, p. 119-131, doi: 10.1016/S0165-232X(00)00007-0.

Franke, D., Hinz, K., Block, M., Drachev, S.S., Neben, S., Kos'ko, M.K. Reichert, C., and Roeser, H.A., 2000, Tectonics of the Laptev Sea region in north-eastern Siberia: Polarforschung, v. 68, p. 51-58.

Goldman, E., 2002, Even in the high Arctic, nothing is permanent: Science, v. 297 , p. $1493-1494$, doi: $10.1126 /$ science.297.5586.1493a.

Gosink, J.P., and Baker, G.C., 1990, Salt fingering in subsea permafrost: Some stability and energy considerations: Journal of Geophysical Research, v. 95, no. C6, p. 9575-9583.

Hinz, K., Delisle, G., and Block, M., 1998, Seismic evidence for the depth extent of permafrost in shelf sediments of the Laptev Sea, Russian Arctic, in Lewkowicz, A.G., and Allard, M., eds., Permafrost: Seventh International Conference Proceedings, Yellowknife, Canada: Quebec, Centre d'études nordiques, Université Laval, Collection Nordicana, v. 57, p. $453-459$.

Hölemann, J.A., Schirmacher, M., Kassens, H., and Prange, A., 1999, Geochemistry of surficial and ice-rafted sediments from the Laptev Sea (Siberia): Estuarine, Coastal and Shelf Science, v. 49, p. 45-59, doi: 10.1006/ecss.1999.0485.

Hölemann, J.A., Schirmacher, M., and Pragne, A., 2005, Seasonal variability of trace metals in the Lena River and the southeastern Laptev Sea: Impact of the spring freshet: Global and Planetary Change, Special Issue, v. 48, no. $1-3$, p. $112-125$, doi: $10.1016 /$ j.gloplacha.2004.12.008, doi: $10.1016 /$ j.gloplacha.2004.12.008.

Ivanova, N.M., Sekretov, S.B., and Shkarubo, S.N., 1990, Geologic structure of the Laptev Sea shelf according to seismic studies: Oceanology (Moscow), v. 29, p. $600-604$.

Johannessen, O.M., Bengtsson, L., Miles, M.W., Kuzmina, S.I., Semenov, V.A., Alekseev, G.V., Nagurny, A.P., Zakharov, V.F., Bobylev, L.P., Pettersson, L.H., Hasselmann, K., and Cattle, H.P., 2004, Arctic climate change: Observed and modelled temperature and sea-ice variability: Tellus, v. 56A, p. $328-341$.

Jokat, W., Ritzmann, O., Schmidt-Aursch, M.C., Drachev, S., Gauger, S., and Snow, J., 2003, Geophysical evidence for reduced melt production on the Arctic ultraslow Gakkel mid-ocean ridge: Nature, v. 423, p. 962-965, doi: 10.1038 /nature 01706 .

Jones, P.D., and Moberg, A., 2003, Hemispheric and large-scale surface air temperature variations: An extensive revision and update to 2001: Journal of Climate, v. 16, p. 206-223, doi: $10.1175 / 1520-0442(2003) 016<0206$ : HALSSA $>2.0 . \mathrm{CO} ; 2$.

Karasik, A.M., 1974, The Eurasia Basin of the Arctic Ocean from the point of view of plate tectonics, in Problems in Geology of Polar Areas of the Earth: Leningrad, Nauchno-Issledovatel'skii Institut Geologii Arktiki, p. 23-31 (in Russian).

Kassens, H., Bauch, H.A., Dmitrenko, I.A., Eicken, H., Hubberten, H.-W., Melles, M., Thiede, J., and Timokhov, L.A., 1999, Land-Ocean Systems in the Siberian Arctic: Dynamics and History: Berlin, Springer, $711 \mathrm{p}$.

Kassens, H., Bauch, H., Dmitrenko, I., Drachev, S., Grikurov, G., Thiede, J., and Tuschling, K., 2001, Transdrift VIII: Drilling in the Laptev Sea in 2000: The Nansen Icebreaker, v. 12 , no. 1 , p. $8-9$.

Larsen, E., Funder, S., and Thiede, J., eds., 1999, Late Quaternary history of northern Russia and adjacent shelves: Boreas, v. 28, no. 1, p. 234-242.

Lindemann, F., Hölemann, J.A., Korablev, A., and Zachek, A., 1999, Particle entrainment in newly forming sea ice-Freeze-up studies in October 1995 , in Kassens, H., Bauch, H.A., Dmitrenko, I.A., Eicken, H., Hubberten, 
H.-W., Melles, M., Thiede, J., and Timokhov, L.A., eds., Land-Ocean Systems in the Siberian Arctic: Dynamics and History: Berlin, Springer, p. 113-124.

Measures, C.I., 1999, The role of entrained sediments in sea ice in the distribution of aluminium and iron in the surface waters of the Arctic Ocean: Marine Chemistry, v. 68 , p. $59-70$, doi: $10.1016 / \mathrm{S} 0304-$ 4203(99)00065-1.

Meese, D.A., Reimnitz, E., Tucker, W.B., III, Gow, A.J., Bischof, J., and Darby, D.A., 1997, Evidence for radionuclide transport by sea ice: The Science of the Total Environment, v. 202, p. 267-278, doi: $10.1016 / \mathrm{S} 0048$ 9697(97)00121-6.

Michael, P.J., Langmuir, C.H., Dick, H.J.B., Snow, J.E., Goldstein, S.L., Graham, D.W., Lehnert, K., Kurras, G., Jokat, W., Mühe, R., and Edmonds, H.N., 2003, Magmatic and amagmatic seafloor generation at the ultraslow-spreading Gakkel Ridge, Arctic Ocean: Nature, v. 423, p. 956-961, doi: 10.1038/nature01704

Monahan, A.H., Fyfe, J.C., and Flato, G.M., 2000, A regime view of Northern Hemisphere atmospheric variability and change under global warming: Geophysical Research Letters, v. 27, p. 1139-1142, doi: 10.1029/1999GL011111.

Müller-Lupp, T., and Bauch, H., 2005, Linkage of arctic atmospheric circulation and Siberian shelf hydrography: A proxy validation using $\delta^{18} \mathrm{O}$ records of bivalve shells: Global and Planetary Change, Special Issue, v. 48 , no. 1-3, p. 175-186, doi: 10.1016/j.gloplacha.2004.12.012.

Müller-Lupp, T., Bauch, H.A., and Erlenkeuser, H., 2003, Seasonal and interannual variability of Siberian river discharge in the Laptev Sea inferred from stable isotopes in modern bivalves: Boreas, v. 32, p. 292-303, doi: 10.1080/03009480310001984.

Mysak, L.A., 2001, Patterns of Arctic circulaţion: Science, v. 293, p. 1269 1270, doi: $10.1126 /$ science. 1064217 .

Nelson, F.E., 2003, (Un)frozen in time: Science, v. 299, p. 1673-1674, doi: 10.1126/science. 1081111

Nürnberg, D., Wollenburg, I., Dethleff, D., Eicken, H., Kassens, H., Letzig, T., Reimnitz, E., and Thiede, J., 1994, Sediments in Arctic sea ice: Implications for entrainment transport and release: Marine Geology, v. 119, p. 185-214, doi: 10.1016/0025-3227(94)90181-3.

Osterkamp, T.E., Baker, G.C., Harrison, W.D., and Matava, T., 1989, Characteristics of the active layer and shallow subsea permafrost: Journal of Geophysical Research, v. 94, no. C11, p. 16,227-16,236.

Pavlov, A.V., 1994, Current changes of climate and permafrost in the Arctic and sub-artic of Russia: Permafrost Periglacial, v. 5, p. 101-110.

Peterson, B.J., Holmes, R.M., McClelland, J.W., Vörösmarrty, C.J., Lammers, R.B., Shiklomanov, A.I., Shiklomanov, I.A., and Rahmstorf, S., 2002, Increasing river discharge to the Arctic Ocean: Science, v. 298, p. 21712173, doi: $10.1126 /$ science. 1077445 .

Pfirman, S., Lange, M.A., Wollenburg, I., and Schlosser, P., 1990, Sea ice characteristics and the role of sediment inclusions in deep-sea deposition: Arctic-Antarctic comparison, in Bleil, U., and Thiede, J., eds., Geological History of the Polar Oceans: Arctic versus Antarctic: NATO Advanced Science Institutes Series, v. C308, p. 187-211.

Pivovarov, S.V., Hollemann, J.A., Kassens, H., Antonow, M., and Dmitrenko, I., 1999, Dissolved oxygen, silicon, phosphorous and suspended matter concentrations during the spring breakup of the Lena River, in Kassens, H., Bauch, H.A., Dmitrenko, I.A., Eicken, H., Hubberten, H.-W., Melles, M., Thiede, J., and Timokhov, L.A., eds., LandOcean Systems in the Siberian Arctic: Dynamics and History: Berlin, Springer, p. 251-264.

Pivovarov, S.V., Hölemann, J., Kassens, H., Piepenburg, D., and Schmid, M., 2004, Laptev and East Siberian seas, in Robinson, A.R., and Brink, K., eds., The Global Coastal Ocean: Interdisciplinary Regional Studies and Synthesis: The Sea, v. 14, p. 1107-1133.

Proshutinsky, A., and Johnson, M., 1997, Two circulation regimes of the winddriven Arctic Ocean: Journal of Geophysical Research, v. 102, p. 12,49312,514, doi: $10.1029 / 97 \mathrm{JC} 00738$.

Proshutinsky, A., Johnson, M., and Proshutinsky, T., 2001, Understanding climatic controls on sea-ice transport pathways in the Arctic Ocean: Annals of Glaciology, v. 33, p. 551-554.

Rahmstorf, S., and Ganopolski, A., 1999, Long-term global warming scenarios computed with an efficient coupled climate model: Climatic Change, v. 43, p. 353-367, doi: 10.1023/A:1005474526406.
Reimnitz, E., McCormick, M., McDougall, K., and Brouwers, E., 1993, Sedi ment export by ice rafting from a coastal polynya, Arctic Alaska, U.S.A. Arctic and Alpine Research, v. 25, p. 83-98, doi: $10.2307 / 1551544$.

Rigor, 1., and Colony, R., 1997, Sea-ice production and transfer of pollutants in the Laptev Sea, 1979m1993: The Science of the Total Environment, v. 202, p. 89-110, doi: 10.1016/\$0048-9697(97)00107-1.

Roeser, H.A., Block, M., Hinz, K., and Reichert, C., 1995, Marine geophysical investigations in the Laptev Sea and the western part of the East Siberian Sea, in Kassens, H., et al., eds., Reports on Polar Research: Bremerhaven, Germany, Alfred Wegener Institute for Polar and Marine Research, v. 176, p. 367-377.

Romanovsky, N.N., Hubberten, H.-W., Gavrilov, A.V., Tumskoy, V.E., and Kholodov, A.L., 2004, Permafrost of the east Siberian arctic shelf and coastal lowlands: Quaternary Science Reviews, v. 23, p. 1359-1369, doi: 10.1016/j.quascirev.2003.12.014.

Romanovsky, N.N., Hubberten, H.-W., Gavrilov, A.V., Eliseeva, A.A., and Tipenko, G.S., 2005, Offshore permafrost and gas hydrate stability zone on the shelf of East Siberia seas, in Rachold, V., Are, F., Atkinson, D. Cherkashov, G., and Solomon, S., eds., Arctic Coastal Dynamics: GeoMarine Letters, v. 25, no. 2-3, p. 167-182.

Savostin, L.A., Karasik, A.M., and Zonenshain, L.P., 1984, The history of the opening of the Eurasia basin in the Arctic: Transactions of the USSR Academy of Sciences, Earth Sciences Section, v. 275, p. 79-83.

Serreze, M.C., Walsh, J.E., Chapin, F.S., III, Osterkamp, T., Dyurgerov, M., Romanovsky, V., Oechel, W.C., Morison, J., Zhang, T., and Barry, R.G., 2000 , Observational evidence of recent change in the northern highlatitude environment: Climatic Change, v. 46, p. 159-207, doi: 10.1023/ A:1005504031923.

Stein, R., Boucsein, B., Fahl, K., Garcia de Oteyza, T., Knies, J., and Niessen, F., 2001, Accumulation of particulate organic carbon at the Eurasian continental margin during late Quaternary times: Controlling mechanisms and paleoenvironmental significance: Global and Planetary Change, v. 31, p. 87-104, doi: 10.1016/S0921-8181(01)00114-X.

Stepanova, A., Taldenkova, E., and Bauch, H.A., 2003, Recent Ostracoda from the Laptev Sea (Arctic Siberia): Species assemblages and some environmental relationships: Marine Micropaleontology, v. 48, p. 23-48, doi: 10.1016/S0377-8398(02)00136-6.

Thiede, J., ed., 2004, Quaternary environments of the Eurasian North: Quaternary Science Reviews, v. 23, no. 11-13, p. 1225-1227, doi: $10.1016 /$ j.quascirev.2003.12.006.

Thompson, D.W., and Wallace, J.M., 1998, The Arctic Oscillation signature in the wintertime geopotential height and temperature fields: Geophysical Research Letters, v. 25, p. 1297-1300, doi: 10.1029/98GL00950.

Tuschling, K., 2000, Phytoplankton ecology in the arctic Laptev Sea-A comparison of three seasons: Reports on Polar Research, v. 347, 144 p.

Viscosi-Shirley, C., Pisias, N., and Mammone, K., 2003, Sediment source strength, transport pathways and accumulation patterns on the SiberianArctic's Chukchi and Laptev shelves: Continental Shelf Research, v. 23, p. 1201-1225, doi: 10.1016/S0278-4343(03)00090-6.

Vogt, P.R., Taylor, P.T., Kovacs, L.C., and Johnson, G.L., 1979, Detailed aeromagnetic investigation of the Arctic basin: Journal of Geophysical Research, v. 84, p. 1071-1089.

Wegner, C., Hölemann, J.A., Dmitrenko, I., Kirillov, S., Tuschling, K., Abramova, E., and Kassens, H., 2003, Suspended particulate matter on the Laptev Sea shelf (Siberian Arctic) during ice-free conditions: Estuarine, Coastal and Shelf Science, v. 57, p. 55-64, doi: 10.1016/ S0272-7714(02)00328-1.

Wegner, C., Hölemann, J.A., Dmitrenko, I., Kirillov, S., and Kassens, H., 2005 , Seasonal variations in arctic sediment dynamics-Evidence from 1-year records in the Laptev Sea (Siberian Arctic): Global and Planetary Change, Special Issue, v. 48, no. 1-3, p. 126-140, doi: 10.1016/ j.gloplacha.2004.12.009.

Winter, B.L., Johnson, C.M., and Clark, D.L., 1997, Strontium, neodymium, and lead isotope variations of authigenic and silicate sediment components from the late Cenozoic Arctic Ocean: Implications for sediment provenance and the source of trace metals in seawater: Geochimica et Cosmochimica Acta, v. 61, p. 4181-4200, doi: 10.1016 / S0016-7037(97)00215-9.

MANUSCRIPT ACCEPTEd By THE SOCIETY 13 DECEMBER 2006 